\title{
Production Smoothness Improvement through ARENAApplication in theFood Manufacturing Industry
}

\author{
A.H. Abdul Rasib ${ }^{1}$, R. Abdullah ${ }^{1}$, N.F. Bazilah ${ }^{1}$, Z. F. Mohamad Rafaai ${ }^{2}$, and R. M. Noor ${ }^{3}$ \\ ${ }^{1}$ Faculti TeknologiKejuruteraanMekanikaldanPembuatan, UniversitiTeknikal Malaysia, Melaka, Hang Tuah Jaya, 76100 \\ Durian Tunggal, Melaka, Malaysia
}

${ }^{2}$ Fakulti KejuruteraanMekanikal, UniversitiTenagaNasional, 43000 Kajang, Selangor, Malaysia

${ }^{3}$ Quality Assurance Division, Panac Advanced Film Malaysia Sdn. Bhd., 13700 Seberang Jaya, Pulau Pinang, Malaysia

Corresponding Author's Email: ${ }^{1}$ amir.hamzah@utem.edu.my

Article History: Received: 10 November 2020; Revised 12 January 2021 Accepted: 27 January 2021; Published online: 5 April 2021

\begin{abstract}
Improvement of manufacturing production is crucial to increase productivity. ARENA is a useful simulation application to imitate the real-time result for measuring productivity. The aim of this research is to execute production smoothness improvement through ARENA simulation application. This is a collection of production information of the selected food industry, as a real case study to construct simulation model in ARENA application. From the simulation, the current manufacturing system of the food industry will be analysed. Based on the issues found,a few improvementswere suggestedfor the system. In order to prove the enforceability of the improved system, the simulation model of the improved system is to construct and analyse its real-time performance via ARENA simulation application. Finally, the most suitable improvement suggestion will be proposed for the food industry. In conclusion, this study had implemented the ARENA application to improve the smoothness of the manufacturing system.

Keywords: $\quad$ production smoothness, production line, productivity, manufacturing system, system simulation
\end{abstract}

\section{Introduction}

In the era of globalisation, manufacturing industries are facing significant challenges with the continuous growth in manufacturing technology. For example,to fulfill the customers' satisfaction, forecast product demand to the market, improve the efficiency in manufacturing operations, intense market competition, technological developments, etc. In the present climate, industries technology has developed towards the fourth stage of industrialisation,known asthe Industry 4.0 [1]. To compete with other industries, a well-arranged manufacturing system helps in optimising and producing innovative products at shortened time-to-market [2]. A good manufacturing system involvedseveral considerations, such as production scheduling, production planning and control, the arrangement of facilities layout, andmany others.

An intelligence production control determines the production smoothness of the manufacturing system. A stepwise decision on the key to success is to have an intelligence production control. The needto change and enhance the manufacturing system into a more efficient and smooth production flow are required to compete with others. However, a changing process incurs a certain risk to the manufacturing companies. Before launching the new management, it is crucial to ensure that the enforceability of the new system contributes a profit for the company. Therefore, the ARENA simulation application is the best way by using the DMAIC process in enhancing the production smoothness of the manufacturing system, and increasing the efficiency of the production flow, without affecting the quality of the product in the least risky way.

The objective of this study is to implementthe production smoothness improvement through ARENA simulation application, as a measurement tool for production performance.

\section{Understanding of Literature Review}

Production planning is very important to ensure the productivity and control of the manufacturing system. It determines the work efficiency and the production smoothness of the manufacturing system.Furthermore, to have a good production planning, most industries use simulation modelling to plan and control the production [3]. It is claimed 
that by using simulation modelling to forecast the reliability in production planning helps the manufacturing system to take appropriate measures that enabled a reliable production schedule in the future. Simulation modelling is a simplified representation of a complex system that provides the predictions of the system's performance measures of interest.

\subsection{Manufacturing Operation}

The manufacturing operation is a large organisation of operations which transforms resources (input) into finished goods (output). According to [4], the manufacturing operations used the given resources, such as raw materials, labour, and utilities to produce a product. In the manufacturing operations, the ability to deliver the product without compromising the product's quality is the key to success in an effective manufacturing operation management. [5] mentioned that short lead times, more variants, low and fluctuating volumes, and low prices were critical requirements for the manufacturing system to improve operational efficiency. Therefore, a good production planning in the manufacturing system is needed to ensure effective manufacturing operation management.

\subsection{Manufacturing System}

[6] said that the manufacturing systems werecharacterised by options and features to process any type of components, parts, pre-established production processes, and customers' requirements. In other words, the manufacturing system is a set of machines, transportation elements, people, storage, computers, and other items that are used together for manufacturing purposes. According to [7], the development of an intelligent manufacturing system comprised intelligent scheduling, process optimisation, control, and maintenance. Therefore, the manufacturing system of a product should be designed, operated, and treated to run effectively.

\subsubsection{Product Type}

Themanufacturing system consisted oftwo processes, which are discrete manufacturing and continuous process manufacturing. Discrete manufacturing is the manufacturing of an individual part or product that is easily distinguishable, count, or touched. [8] said that the discrete manufacturing process used a bill of material (BOM), which assembled the product-based in the assembly line. Continuous process manufacturing operates on a product that is continually flowing. In a continuous process, the product is manufactured by using a formula or production flow, for instant oil refineries and chemical industries which produced pharmaceuticals, food and beverages, refined oil, paints,etc. Therefore, it is important to define the product type of the manufacturing process. Thereafter, choose a suitable manufacturing process to produce the product for optimising the productivity and efficiency of the manufacturing system [9].

\subsubsection{Product Variety}

The product variety is the degree of the system capable of dealing with variation in the parts or products. There are two product variety, which are single-model and multiple-model manufacturing. Single-model is the production of a product that is identical, while multiple-model is a product that is produced in batches. According to [10], a product variety management strategy had different impacts on performance depending on the level of product customisation. This was due to the product variety management strategy which influenced both supply chain cost and customer service performance. Therefore, product variety is important to increase the profitability of the manufacturing system.

\subsubsection{Production Planning and Control}

Production planning plays a critical role in shorter product life cycles, improve the processes performance, increase the product flexibility, and optimise the machine utilities in a manufacturing system. On the other hand, production control ensures the implementation of all plans for production, such as initiation of production, dispatching of items, monitoring of production activities amongst others. 


\subsubsection{Facilities Layout}

The facility layout considers available space, final product, the safety of users and facility, and convenience of operations [11]. There are four types of facility layout: fixed-position layout, product layout, cellular layout, and process layout. Facility layout planning is to design an effective workflow to ensure that the equipment and workers are more productive. Facility layout planning is important to minimise the total distance of goods flow, the material handling cost, and the time spent in the manufacturing system[12]. According to [13], well-designed facilities resulted in efficient materials handling, reduced resource transportation time, and decreased production cycle time.

\subsection{ARENA Simulation}

[2]mentioned that the manufacturing systems simulation is a powerful tool for designing and evaluating a manufacturing system due to its minimal cost, quick analysis, low risk, and might provide meaningful insights, thus, improving the understanding of the influence of each component. ARENA software is one of the most popular simulation software used in industries. ARENA simulation software is a discrete event simulation programme and automation software developed by Systems Modelling and acquired by Rockwell Automation. ARENA modelling system is a flexible and powerful tool for industry analysts to create a simulation model that represents an industrial system.

\subsubsection{Modelling}

In ARENA, an experiment model is built by placing modules that represent processes or logic.To create a module in the ARENA simulation, there will be three important logics: seize, delay, and release. Seizeis the entity which waits until the resource is available. The delay is the entity which holds for processing. While, the release is when the entity is completed and ready to go to the next process. Every module has specific actions relating to the entities, flow and timing, the precise representation of each module, and the entity relative to real-life objects. Once the modules are set-up, the connector lines are used to join these modules together and to specify the flow of entities.

\subsubsection{Animation}

Animating the simulation model is to show a clear picture of the manufacturing process. [14] mentioned that the animation interface of the simulation model was established as a result of the implementation of all the steps in the ARENAsimulation software. Besides, to get a clear and interesting animation, the ARENA softwarecan set the desired picture, for example, workers, machines, products, etc.

\subsubsection{Model Verification}

Once the simulation model is completed, it will show the result of the model and the next step is to verify the model. According to [15], model verification was often defined as "ensuring that the computer programme of the computerised model and its implementation are correct". In the ARENA simulation, the results showed detailed information after completing the simulation model. After obtaining the results, the model verification process was conducted based on the purpose of the manufacturing process, for example, to maximise the profit for the industry, cost and time savings, and to fulfill the customer's requirement. If at this stage the processcannot achieve the requirements, the model cannot be verified until it achieves the requirements. Furthermore, [15] also mentioned that the development of a simulation model should not progress to the next stage of development until the model had satisfied the verification and validation requirements in its current stage.

\subsubsection{Result of Analysis}

Analysis of the simulation result is important to estimate the performance of the system. According to [16], by simulating the data the problems could be identified from the existing system for instance, the occurrence of bottlenecks, waiting time, etc. Therefore, based on the result of the analysis, the industry couldidentify the problems, for example, bottleneck of the system, and unnecessary process. Thereafter, improvements can be done based on the identified 
problems to enhance the productivity, smooth the production line, fulfill the market demand, and increase the profitability of the manufacturing system.

\subsection{ARENA Simulation Application}

ARENA simulation software helps in documenting, visualising, and demonstrating the dynamics of a process with animation. ARENA simulation applications enable models to run quickly, analyse data, and build graphically animated model. ARENA has different types of simulation, which are static, dynamic, continuous, discrete, and deterministic vs discrete. Hence, ARENA simulation isable to model and simulate many types and fields of system activities.

\subsubsection{Workflow Management}

Workflow is a predefined set of process required to get the desired result. A workflow consists of the expected outcomes and the potential steps to achieve the requirements. Workflow management handles those aspects of the process and requirement involving the coordinated execution of multiple tasks. Workflow helps to predefine the process and eliminate unnecessary steps in the manufacturing system. By having workflow management, it helps to reduce the risk and improve productivity.ARENA simulation software is one of the workflow management software which helps to preset the workflow of the manufacturing system.

\subsubsection{Bottleneck Identification and Line Balancing}

Line balancing is important to be considered in the production line to balance the workload between workstations, and helps to reduce the bottleneck of the production. ARENA simulation software analyses and identifies the bottleneck, such as queue build-ups and over-utilisation of resources. By using the simulation method, it was found that the overall alternative model was better than the actual production line model for all characteristics, i.e., content, average time, output, smoothing index, number of operators, and production capacity.

\subsubsection{Production Lot Scheduling}

Production lot scheduling is important to produce the required product based on the inventory size and market, and customers' demands. [17]said that lot-sizing scheduling helped to determine the cycle time and level of production to meet product demand over a finite planning horizon. The production lot-sizing scheduling plays an important role in minimising the inventory cost, setup cost, and lead time. ARENA simulation software helps in the production lot-sizing by showing the result of the cycle time, and the production in a specific time.

\subsubsection{Production Line Design}

An optimal facility layout is an effective tool in cost reduction by enhancing productivity. The production line design includes the manufacturing process or arrangement of the workflow through the sequence of operations starting from the raw materials to the final product. The best possible line layout is important to increase the flexibility of the production. According to [18], a good workstation layout could help to minimise the material handling time and reducedthe operation cycle time as much as possible. By using ARENA simulation software, an operation of the production lines can be set as a workstation or call plant. The combination of the workstations will become the layout of the process, which is also known as a model. The process layout will be clearly shown in the ARENA simulation and helps to analyse and improve easily.

\subsubsection{Material Handling and Inventory Management}

Material handling is a movement, handling, and storing process which controls materials from raw material until packaging. According to [19], material handling system was to ensure that the right amount of material was carefully delivered to the desired destination at the right time, and at a minimum cost. By using the ARENA simulation software, it can optimise the planning of staff, equipment, or material requirements for the model. 
In a nutshell, a manufacturing operation is the organisation of the process which produces. While a manufacturing system is a set of machines, transportation elements, people, storage, computers, and other items that are used together. A good production planning is very important to increase the productivity and efficiency of a manufacturing system. Before starting the production planning, firstly, the product type and the product variety should be clearly defined. This is due to different kind of products require different production planning to obtain the optimised result in aspects of productivity, profitability, and quality.

Simulation of a manufacturing system is a powerful tool for designing, evaluating, and analysing the result of each process of the production line. Amongst the simulation software, ARENA simulation had been chosen,for the software offers the easiest and fastest tools to do the logic diagram [20]. The result of the ARENA simulation provides visuals of the working performance along with the whole system. Based on the gained result, the bottleneck of the system could be defined easily. The result of the analysis had also become more manageable through using ARENA simulation. Therefore, ARENA simulation plays an important role in the production planning because it quickly examines the manufacturing system's problems and solve the problems through the result analysis.

\section{Methodology}

\subsection{The Detailed Process Flow Methodology}

Figure 1shows the detailed process flowmethodology that represents the steps and methods used to realise the aim and objectives of this study.

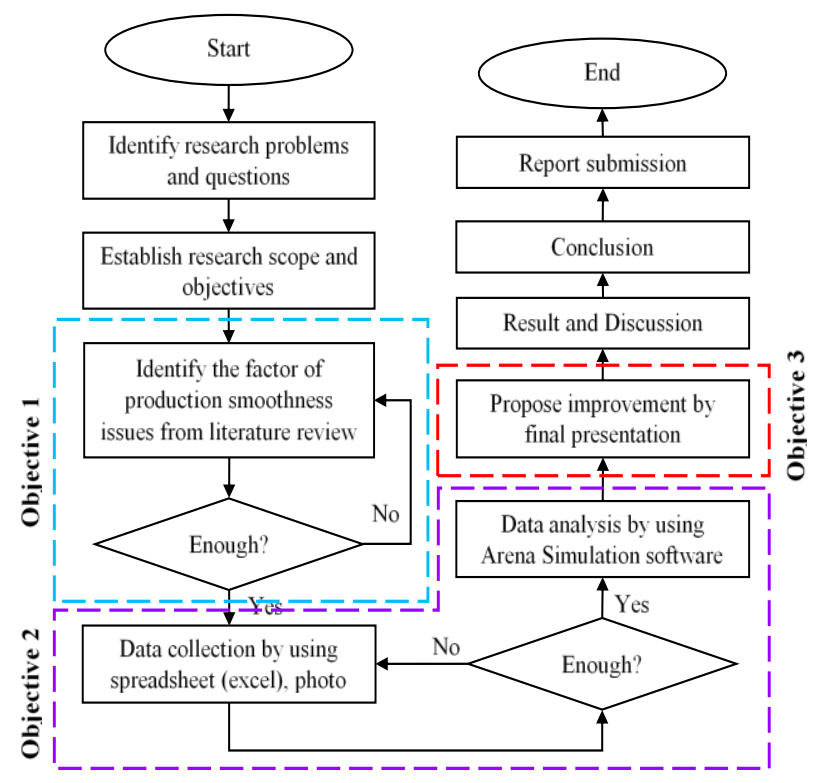

Figure 1. Detailed process flow of research methodology

\subsection{ARENA Simulation Application}

ARENA application is a simulation process of the manufacturing system. ARENA simulation helps in understanding the system through modelling, which isbased on the obtained data, construct, and model of the system via ARENA software. Thereafter, to do the simulation to obtain information about the manufacturing system in the food industry.ARENA simulation indicates the result as the changing of variables. This can help in improving the system by determining the problems of the system and demonstrate the outcomes of the result. 


\section{Result and Discussion}

A real case study of a food industry was conducted to complete this project. The data collection, result ofARENA simulation, data analysis, and the proposed improvement will be discussed to improve the production smoothness of the food industry.

\subsection{Data Collection}

Figure 2 shows the soybean process flow chart; Figure 3 shows the soybean facility layout, and Table 1 shows the data collection for soybean drinks production. All the information was the data collected from thefood industry.

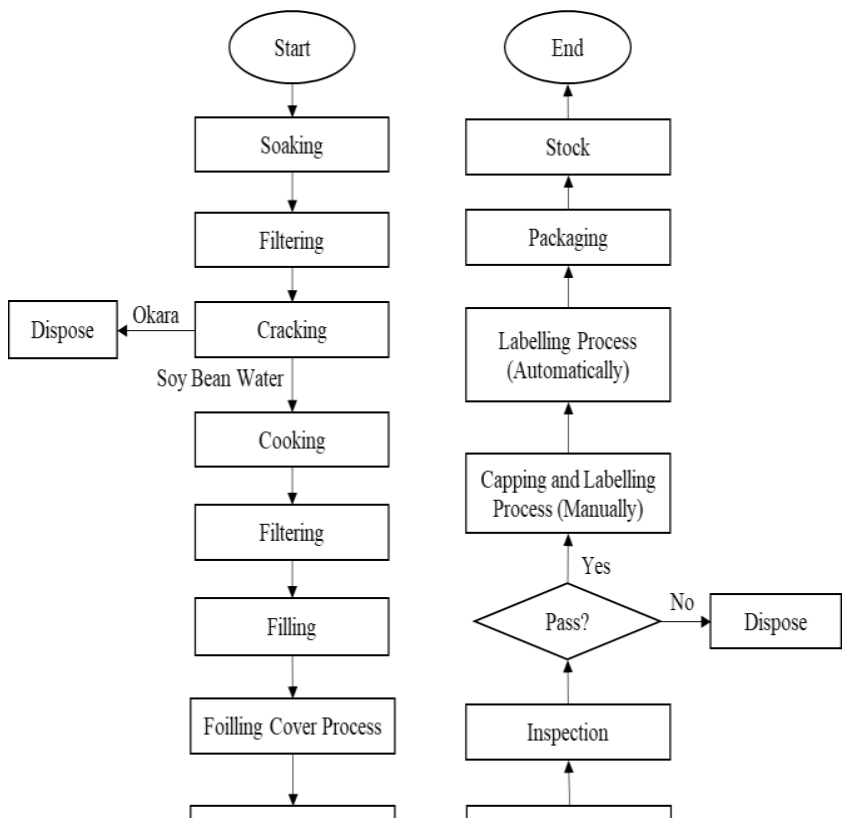

Figure 2. Soybean process flow chart
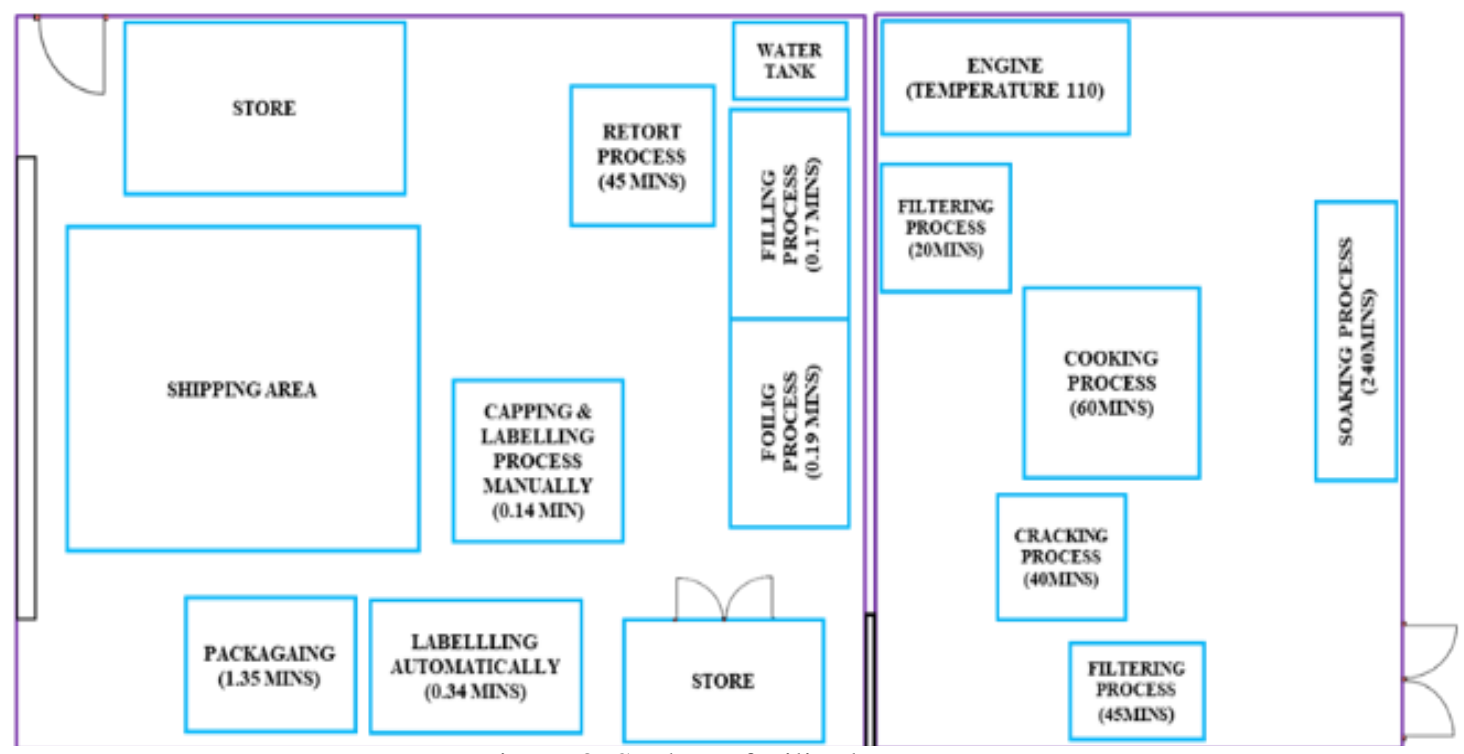

Figure 3. Soybean facility layout 
Table 1. Data collection for soybeanproduction

\begin{tabular}{|c|c|c|c|c|c|c|c|}
\hline \multirow{2}{*}{ Process } & \multirow{2}{*}{$\begin{array}{c}\text { No. of } \\
\text { Workers }\end{array}$} & \multirow{2}{*}{$\begin{array}{c}\text { No. of } \\
\text { Machines }\end{array}$} & \multicolumn{4}{|c|}{ Process Time (min) } & \multirow{2}{*}{ Unit } \\
\hline & & & 1 & 2 & 3 & Average & \\
\hline Soaking & 1 & - & 240 & - & - & 240 & 1 Batch \\
\hline Filtering & 2 & - & 45 & - & - & 45 & 1 Batch \\
\hline Cracking & 2 & 1 & 40 & - & - & 40 & 1 Batch \\
\hline Cooking & 1 & 1 & 30 & - & - & 30 & 1 Batch \\
\hline Filtering & 1 & - & 60 & - & - & 60 & 1 Batch \\
\hline Filling & 1 & 1 & 0.167 & 0.15 & 0.183 & 0.167 & $\begin{array}{l}8 \\
\text { Bottles }\end{array}$ \\
\hline Foiling & 2 & 1 & 0.217 & 0.18 & 0.2 & 0.189 & $\begin{array}{l}8 \\
\text { Bottles } \\
\end{array}$ \\
\hline Retort & 1 & 1 & 50 & - & - & 50 & 1 Batch \\
\hline Cleaning & 2 & - & 30 & - & - & 30 & - \\
\hline Capping (Manual) & 3 & - & 0.138 & 0.141 & 0.148 & 0.1423 & 1 Bottle \\
\hline Labelling (Automatic) & 2 & 2 & 0.367 & 0.333 & 0.333 & 0.3443 & $\begin{array}{l}3 \\
\text { Bottles } \\
\end{array}$ \\
\hline Packaging & 3 & 1 & 1.4 & 1.333 & 1.317 & 1.35 & 1 Carton \\
\hline
\end{tabular}

Total Output $=1,645$ (68 Cartons)

Total Failure $=3$ Bottles

\subsection{Data Analysis}

After completing the ARENA simulation, the result will be obtained, and the next step is to analyse the simulation result. Another way to do the data analysis is by using the why-why analysis tool to help in identifying the root cause of this production process, which include defining the existing problems, and identifyingtheir root cause. Thereafter, based on the causes, to propose actions to be taken to avoid the same problems from occurring.

\subsubsection{ARENA Simulation Analysis}

Figure 4shows the ARENA simulation model of soybean production. From the simulation result, as shown in Table 2, the number out of the system was 70 cartons which were about 1,680 bottles of soybean drinks.

Table 2 also shows the waiting time of the soybean production process. The bottleneck of the process wasdefined from the waiting time of the soybeanproduction process. The process with the highest value of average waiting time means that the process will be the bottleneck of the system. By comparing with the waiting time, the soaking process had the highest value of waiting time, hence the bottleneck process would be the filtering. However, the soaking process time was fixed for the soybean wererequiredto be soaked for at least four hours. Therefore, although the soaking process is the bottleneck process of soybean production, the improvement will not focus on the soaking process.

The second highest average waiting time is the second filtering process. Similar to the soaking process, the second filtering process cannot be rushedfor the soybean drink is hot and needs time to cool down. Consequently, the third highest value of average waiting time was the process that needs to be improved, which was the capping manually process. 


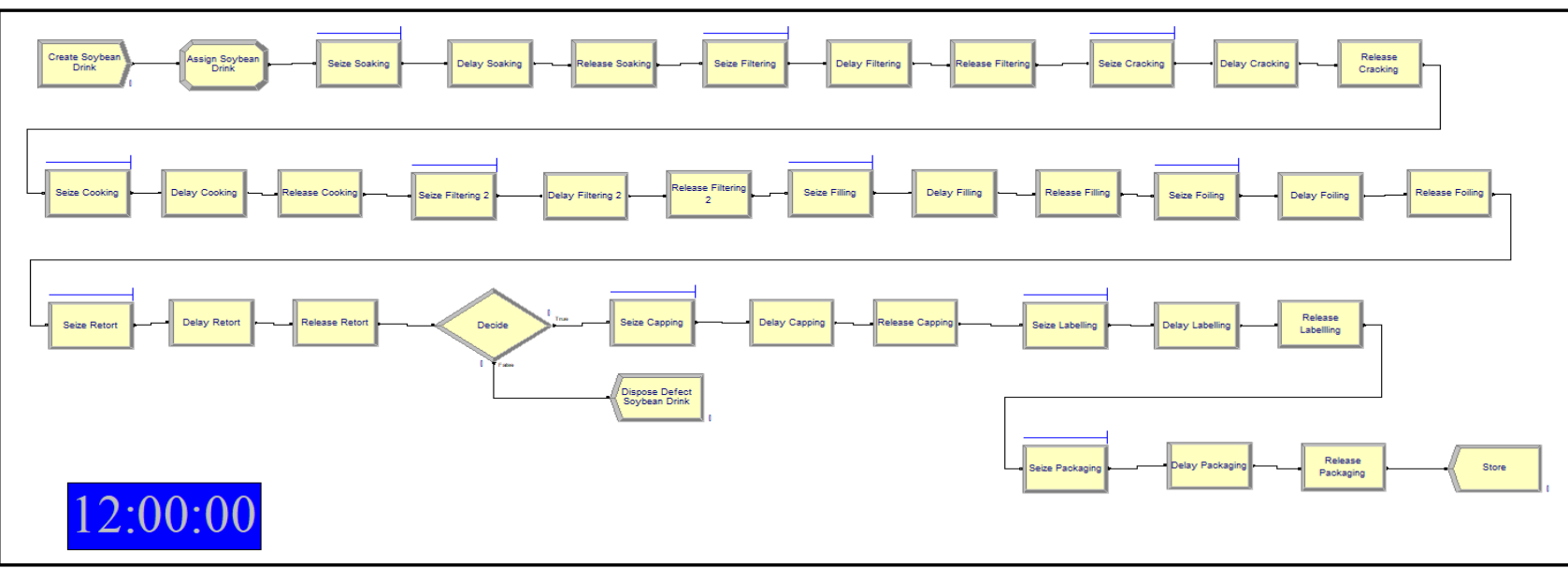

Figure 4.ARENAsimulation of soybean production

Table 2. Waiting time of soybean production process

\begin{tabular}{|c|c|c|c|c|}
\hline Queue & & & & \\
\hline \multicolumn{5}{|l|}{ Time } \\
\hline Waiting Time & Average & Half Width & $\begin{array}{l}\text { Minimum } \\
\text { Value }\end{array}$ & $\begin{array}{l}\text { Maximum } \\
\text { Value }\end{array}$ \\
\hline Seize Capping.Queue & 23.1353 & (Insufficient) & 0.00 & 49.8997 \\
\hline Seize Cooking.Queue & 0.2421 & (Insufficient) & 0.00 & 2.1103 \\
\hline Seize Cracking Queue & 2.8528 & (Insufficient) & 0.00 & 5.4267 \\
\hline Seize Filling Queue & 0.3065 & (Insufficient) & 0.00 & 1.8975 \\
\hline Seize Filtering 2.Queue & 47.5339 & (Insufficient) & 13.7857 & 258.56 \\
\hline Seize Filtering. Queue & 157.54 & (Insufficient) & 2.0035 & 275.47 \\
\hline Seize Foiling.Queue & 0.5614 & (Insufficient) & 0.00 & 4.4739 \\
\hline Seize Labelling. Queue & 20.0902 & (Insufficient) & 0.00 & 53.1265 \\
\hline Seize Packaging. Queue & 1.6920 & (Insufficient) & 0.00 & 8.7175 \\
\hline Seize Retort.Queue & 0.4889 & (Insufficient) & 0.00 & 2.6084 \\
\hline Seize Soakina Queue & 139.56 & (Insufficient) & 0.00 & 272.34 \\
\hline
\end{tabular}

\subsubsection{Why-why Analysis}

Table 2 shows the root causes of production smoothness issues in the soybean production line.Based on the results of the why-why analysis, the three main factorscausing production smoothness issues in thefood industrywere manpower, machine, and method of conduct. Formanpower, the problem was that the lead time was too long. The root cause of this problem waslack of market demand, and lack of training for the workers. As for the machine that needs to share with another production line, the root cause of this problem wasthat the machine did not have routine maintenance and did not have a person-in-charge. For the method issues, which were a fully manual process - capping process, the root cause wasthat the capping process did not provide supporting tools, and it required continuous improvement. 
Table 2. Why-why analysis in soybean production line

\begin{tabular}{|c|c|c|c|c|c|c|c|}
\hline $\begin{array}{c}\text { Main } \\
\text { Factor }\end{array}$ & Problem & Why 1 & Why 2 & Why 3 & Why 4 & Why 5 & Root Cause \\
\hline \multirow{3}{*}{ Man } & \multirow{3}{*}{$\begin{array}{l}\text { Lead time too } \\
\text { long. }\end{array}$} & \multirow{3}{*}{$\begin{array}{l}\text { Workers' } \\
\text { poor } \\
\text { performance } \\
\text { at work }\end{array}$} & $\begin{array}{l}\text { Lack of } \\
\text { motivation }\end{array}$ & $\begin{array}{l}\text { Too much } \\
\text { free time }\end{array}$ & Less work & $\begin{array}{l}\text { Lack of } \\
\text { market } \\
\text { requirement }\end{array}$ & $\begin{array}{l}\text { No market } \\
\text { demand }\end{array}$ \\
\hline & & & \multirow{2}{*}{$\begin{array}{l}\text { Low } \\
\text { efficiency }\end{array}$} & $\begin{array}{l}\text { Lack of } \\
\text { experience }\end{array}$ & Lack of training & $\begin{array}{l}\text { No person-in- } \\
\text { charge of } \\
\text { training }\end{array}$ & \multirow[b]{2}{*}{$\begin{array}{l}\text { Lack of } \\
\text { training }\end{array}$} \\
\hline & & & & $\begin{array}{l}\text { Lack of } \\
\text { knowledge }\end{array}$ & $\begin{array}{l}\text { No proper work } \\
\text { instruction } \\
\text { provided }\end{array}$ & $\begin{array}{l}\text { No person-in- } \\
\text { charge to } \\
\text { provided } \\
\text { instruction }\end{array}$ & \\
\hline \multirow[b]{2}{*}{ Machine } & \multirow{2}{*}{$\begin{array}{l}\text { Labelling } \\
\text { machine } \\
\text { sharing with } \\
\text { other } \\
\text { production } \\
\text { lines. }\end{array}$} & \multirow[b]{2}{*}{$\begin{array}{l}\text { Machine } \\
\text { malfunction }\end{array}$} & Old machine & $\begin{array}{l}\text { Do not have } \\
\text { maintenance }\end{array}$ & $\begin{array}{l}\text { Company } \\
\text { conduct routine } \\
\text { maintenance }\end{array}$ & 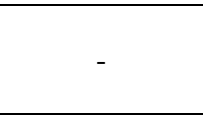 & $\begin{array}{l}\text { Do not have } \\
\text { routine } \\
\text { maintenance }\end{array}$ \\
\hline & & & $\begin{array}{l}\text { Improper } \\
\text { handling of } \\
\text { machine }\end{array}$ & $\begin{array}{l}\text { Workers' } \\
\text { lack of } \\
\text { knowledge }\end{array}$ & $\begin{array}{l}\text { Workers do not } \\
\text { follow SOP }\end{array}$ & $\begin{array}{c}\text { No } \\
\text { supervision }\end{array}$ & $\begin{array}{l}\text { Do not have } \\
\text { person-in- } \\
\text { charge }\end{array}$ \\
\hline \multirow{2}{*}{ Method } & \multirow{2}{*}{$\begin{array}{l}\text { The capping } \\
\text { and labeling } \\
\text { process } \\
\text { requires more } \\
\text { time to } \\
\text { complete. }\end{array}$} & \multirow{2}{*}{$\begin{array}{l}\text { Manual } \\
\text { process }\end{array}$} & \multirow{2}{*}{$\begin{array}{l}\text { Require } \\
\text { capping and } \\
\text { labelling one } \\
\text { by one }\end{array}$} & $\begin{array}{l}\text { No } \\
\text { supporting } \\
\text { tools }\end{array}$ & - & - & $\begin{array}{l}\text { Do not } \\
\text { provide } \\
\text { supporting } \\
\text { tools }\end{array}$ \\
\hline & & & & $\begin{array}{l}\text { No proper } \\
\text { specific } \\
\text { method }\end{array}$ & $\begin{array}{l}\text { Lack of strong } \\
\text { support in } \\
\text { method of } \\
\text { improvement }\end{array}$ & - & $\begin{array}{l}\text { Lack of strong } \\
\text { support by } \\
\text { management }\end{array}$ \\
\hline
\end{tabular}

\subsubsection{Comparison of Original and Improved Models (ARENA simulation)}

After referring to the result of the ARENA simulation and the why-why analysis, the manually capping process was proposed forimprovements. The improvement of the capping process was done by using the helping tools or setting a limited time for the workers to finish the process.

Subsequently, the changing value in the manual capping process was set to obtain the simulation result after implementing the improvement. Table 3 shows the result of the comparison between the original and improved models.

Table 3. Comparison of original model and improved model

\begin{tabular}{|l|l|l|}
\cline { 2 - 3 } \multicolumn{1}{c|}{} & Original Model & Improved Model \\
\hline Process & \multicolumn{2}{c|}{ Same } \\
\hline
\end{tabular}




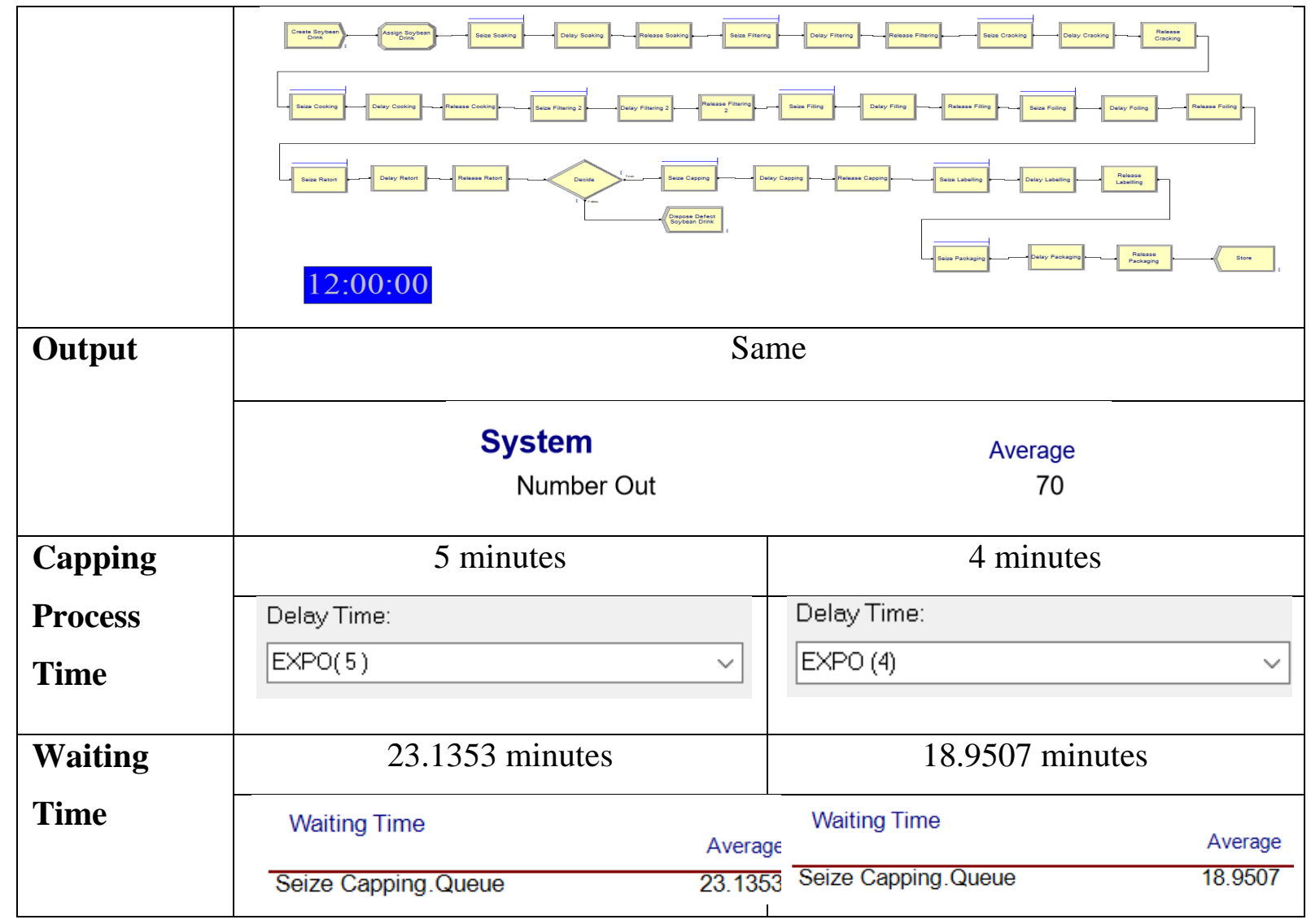

After the simulation of the improved model, there was a reducing value in the average waiting time from 23.1353 minutes to 18.9507 minutes. Therefore, the improvement was verified and the processing time was decreased in the soybean production. This means there wereproduction smoothness improvement in the soybean production system.

\section{Conclusion}

Based on the results, the ARENA simulation application is a useful tool that helps to optimise the current manufacturing system in the industry. In addition, the ARENA application isable to monitor the lead time of production. By analysing the result, it helps to identify the system's constraints and limitations. Besides, ARENA application also allows the analysis of the modified system to look at the capital, and the system performance before investing or changing.

In this study, ARENA application had been implemented to the manufacturing system of the food industry. Based on the investigation of the manufacturing system in the industry, the first objective of this project was completed, which was to identify the factor of production smoothness issues in the soybean production system. Next, the system simulation based on the collected primary and secondary data in the soybean production process was done. The simulation result assisted in identifying the system's constraints and limitations, and the reasons behind specific system conditions. Therefore, the second objective was also fulfilled, which was to construct and analyse the current manufacturing system via the ARENA application.

The final objective of this project was to propose improvement based on the new ARENA simulation. The why-why analysis method wasconducted to identify the root cause of the issues. The why-why analysis is a powerful tool to identify the root cause of the problems in Lean management. Therefore, the solutions were proposed based on 
the root causes as defined in the manufacturing system. The improvement was implemented into the old simulation system, and the performance had been observed.

\section{Acknowledgement}

The author would like to extend a special thank you to the FRGS-RACER/2019/FTKMP-COSSID/F00412
grant, Centre for Research and Innovation Management
(CRIM), FakultiTeknologiKejuruteraanMekanikaldanPembuatan, UniversitiTeknikal Malaysia, Melaka, and the participating food industry for the use of facilities and providing useful data in order to complete this study.

\section{References}

[1] Stock, T., andSeliger, G., 2016. Opportunities of Sustainable Manufacturing in Industry 4.0. Procedia CIRP, 40(Icc), pp. 536-541.

[2] Mourtzis, D., Doukas, M., andBernidaki, D., 2014. Simulation in manufacturing. Procedia CIRP, 25(C), pp. 213229.

[3] Schuh, G., Potente, T., andHauptvogel, A., 2014. Methodology for the Evaluation of Forecast Reliability of Production Planning Systems. Procedia CIRP, 17, pp. 469-474.

[4] Bracciotti, M., 2017. Operational Management Study. Robert Gordon University Aberdeen.

[5] Eguía, I., Villa, G., and Lozano, S., 2017. Efficiency Assessment of Reconfigurable Manufacturing Systems. Procedia Manufacturing, 11(June), pp. 1027-1034.

[6] Monika, B., Vavrík, V., andGašo, M., 2019. Future of the Manufacturing Systems. Průmyslovéinženýrství Conference, January 2019, pp. 35-42.

[7] Liang, S., Rajora, M., Liu, X., Yue, C., Zou, P., andWang, L., 2018. Intelligent Manufacturing Systems. International Journal of Mechanical Engineering and Robotics Research, 7(3), pp. 324-330.

[8] Jim O'Donnell, 2017. Discrete Manufacturing. Enterprise Resource Planning (ERP) Resource Center. Retrieved March 19, 2020.

[9] Goldense, B. L., 2018. The 6 Types of Manufacturing Processes: The impact of AM. Machine Design, 90(9), pp. 104.

[10] Um, J., Lyons, A., Lam, H. K. S., Cheng, T. C. E., and Dominguez-Pery, C., 2017. Product Variety Management and Supply Chain Performance: A Capability Perspective on Their Relationships and Competitiveness Implications. International Journal of Production Economics, 187, pp. 15-26.

[11] Kikolski, M., andKo, C. H., 2018. Facility layout design. Engineering Management in Production and Services, 10(3), pp. 70-79.

[12] Kovács, G., andKot, S., 2017. Facility Layout Redesign for Efficiency Improvement and Cost Reduction. Journal of Applied Mathematics and Computational Mechanics, 16(1), pp. 63-74.

[13] Prajapat, N., Waller, T., Young, J., and Tiwari, A., 2016. Layout Optimisation of a Repair Facility Using Discrete Event Simulation. Procedia CIRP, 56, pp. 574-579.

[14] Gundogar, E., Sari, M., andKokcam, A. H., 2016. Dynamic Bottleneck Elimination in Mattress Manufacturing Line Using Theory of Constraints. SpringerPlus, 5(1), pp. 1-15.

[15] Sargent, R. G., 2011. Verification and Validation of Simulation Models. Proceedings of the 2011 Winter Simulation Conference, pp. 183-198.

[16] Jilcha, K., andBerhan, E., 2015. Workers and Machine Performance Modelling in Manufacturing System Using ARENA Simulation. Journal of Computer Science \& Systems Biology 2015, 8(4), pp. 185-190.

[17] Almada-Lobo, B., Clark, A., Guimarães, L., Figueira, G., andAmorim, P., 2015. Industrial Insights into Lot Sizing and Schedulingmodelling. PesquisaOperacional, 35(3), pp. 439-464.

[18] Bon, A. T., andShahrin, N. N., 2016. Assembly Line Optimisation Using ARENA Simulation. Proceedings of the International Conference on Industrial Engineering and Operations Management, 8-10 March, pp. 2225-2232.

[19] Dongre, AbhilashaandMohite, N. Y., 2015. Significance of Selection of Material Handling System Design in Industry. International Journal of Engineering and General Science, 3(2), pp. 76-79.

[20] Rostkowska, M., 2014. Simulation of Production Lines in the Education of Engineers: How to Choose the Right Software? Management and Production Engineering Review, 5(4), pp. 53-65. 